\title{
Re-animating church as politics: South Africa commemorating the radical reformation in the hope of decolonizing local congregations ${ }^{1}$
}

\author{
Goddard, Allen J \\ University of KwaZulu-Natal \\ GoddardA@ukzn.ac.za
}

\begin{abstract}
An unlikely crosscurrent in the Reformation-schism was the violent reaction of both the Reformation and Roman Catholic establishments in the 1520s to Anabaptist Churches. What evoked this reaction was the Anabaptists' recognizably distinct church polity, which the Radical Reformers understood to be directly continuous with the socially transformative politics of Jesus and of the first Christians of the Roman Empire. In a spirit of contrition for Christian disunity, this research is a commemoration that aims to identify prophetic aspects of early Anabaptist polity. Secondly, the essay demonstrates that the way the Radical Reformers practised church is pertinent for ecclesiology five centuries later - not least in contemporary South Africa and North America where church capture to neoliberal economic values and commitments prior to following Jesus, calls into question orthodox Christian witness and presence. Thirdly, the essay imagines a South African re-appropriation of the politics of Jesus as amplified in the Radical Reformation tradition, in a tentative, heuristic invitation to the Church in South Africa today, to become 'God's left wing'.
\end{abstract}

Key words

radical Reformation; transformative politics; neoliberal; economic values

1 This study is dedicated to the memory of Dr Alan Kreider (d. 8 May 2017). 
[...] the church, for some quite understandable reasons, is constantly tempted to imitate the false politics of the world for its own life. ${ }^{2}$

[...] the church does not have a social ethic, but rather is a social ethic. $^{3}$

So if anyone is in Christ, there is a new creation... ${ }^{4}$

\section{Introduction}

A reading of the New Testament, at face value, or from almost any hermeneutical stance, presents a Trinitarian grammar of God's Kingdom that parses Jesus as subject. ${ }^{5}$ The transitive verb is the action of Father, Son and Spirit in the workings of God's Trinitarian economy throughout creation. The direct object of God's transformation is the local congregation, and with the Church, all other living creatures - that miraculous outbreak on Earth of God's already, not yet, new creation. ${ }^{6}$ This grammar of the Kingdom was embodied by the first disciples who received it through the Beatitudes, the Sermon on the Mount and pre-eminently in the Messiah who modelled Kingdom grammar as his life of cruciform love, celebration, sufferings, death and Resurrection. The necessity to incarnate this grammar of God's Kingdom was clearly understood by the first Christians of the ante-Nicaean church who practised a cruciform discipleship at the margins of a cruel empire. Early Christians became martyrs because the politics

2 Stanley Hauerwas, In Good Company: The Church as Polis (Notre Dame, IND: University of Notre Dame Press, 1995), p. 8.

3 Ibid., 22.

42 Corinthians 5:17a quoted from the New Revised Standard Version

5 Expositions of this Trinitarian grammar by scholars from the Orthodox and Pentecostal poles of Christian orthodoxy respectively, are John Zizioulas, Being as Communion: Studies in Personhood and the Church, Contemporary Greek Theologians Series No. 4 (Crestwood, NY: St Vladimir's Press, 1985) and Miroslav Volf, After Our Likeness: The Church as the Image of the Trinity (Grand Rapids, MI: Eerdmans, 1998).

6 This research has no interest in denominational polity but is animated by the possibilities of a politics of the local church - that is corporate Christian spirituality in the day-today appropriation of the Sermon on Mount by disciples in local congregations. For a classic exposition, see Dietrich Bonhoeffer's Life Together (London: SCM, 1954). I am thankful to James Houston whose courses on Trinitarian Theology introduced me to Patristic theology, enabling me to apprehend the indispensability of creation and creatureliness in God's eternal purpose. For a contemporary exposition of the recapitulation of creation at the Eschaton, see Tom Wright, Surprised by Hope (London: SPCK, 2007). 
and economics of their congregational life were perceived as a threat to the politics and economics of Empire. ${ }^{7}$ Theologically, this pattern of life in first century churches has been described as the first fruits of God's miraculous, counter-cultural new creation (2 Cor 5:17; James 1: 19-20).

Two thousand years later in North America and South Africa, in 2017, embodiment of this grammar of God's Kingdom in local congregations is gravely in question. ${ }^{8}$ It might be said that this is because the metaphorical ground on which local congregations in North America and South Africa worship is bloodied or polluted and cries out for cleansing after so many painful accommodations of North American and South African Christians to the worst abuses of capitalism during colonialism. ${ }^{9}$

In the longer reach of Church history since Constantine, similar accommodations to the coercive politics and economics of Empire have distorted a true embodiment of the grammar of God's Kingdom in local churches. Constantine's marriage of State and Church in the fourth century appears to have scrambled the grammar of God's Kingdom. Christendom may be understood to have confused direct object for verb or even subject, which irrevocably changed earlier congregational embodiments of the grammar of God's Kingdom. ${ }^{10}$ Churches in the pocket of Empire apparently forgot a foundational truth of baptismal and ecclesial identity - the local church is the direct object of God's dynamic, transforming action

7 'Empire' used in the generic sense refers to empires and political hegemonies across the ages.

8 See for example, Sojourners: History will Judge Today's Christians According to These 4 Questions, Stephen Matthson, 17 February 2016. [Online] Available: https://sojo.net/ articles/4-moral-questions-facing-modern-christianity [Accessed: 24 August 2017].

9 A historical introduction to Protestant inveiglement with Empire is Brian Stanley, The Gospel and the Flag: Protestant Missionaries \& British Imperialism in the Nineteenth \& Twentieth Centuries (Leicester: Apollos, 1990).

10 Literature on the impact of Christendom, Constantine's gradual merger of Church and State after 312 A.D., on the polity, theology and spirituality of the Church is vast. An introduction to Christendom's alteration of first century churches' theology and ecclesiology is Alan Kreider, The Change in Conversion and the Origin of Christendom (Eugene Oregon: Wipf \& Stock, 2007). Also see Kreider's The Patient Ferment of the Early Church: The Improbable Rise of Christianity in the Roman Empire (Grand Rapids, MI: Baker Academic, 2016). 
Proofs of a distorted grammar of God's kingdom accompany the many coercive transitive verbs of Church history - verbs enacted by Christian disciples from local congregations in order to effect perverse objectives. Conversion by the sword, the Crusades, the Spanish Inquisition, Slavery, Pogroms against the Jews, the many Wounded Knees of North America, the Stolen Generations of aboriginal people and of First Nations in Australia and Canada, and most consequentially, at Auschwitz, in Apartheid South Africa and in neo-colonial Rwanda.

Today's world in which local communities have been colonized to a greater or lesser degree to service a globalized economy, is described by Achille Mbembe as a world determined by the coercive powers of capitalism - 'the power of capture, influence and polarization [which] has always depended on racial subsidies to exploit the planet's resources." 11 The complicity of Christendom, that is Christian leaders and local congregations, in support of what Mbembe calls a two-sided capitalist world practising 'unlimited violation of all forms of prohibition [on the one hand] and, on the other, the abolition of any distinction between ends and means,' may not be forgotten or explained away. ${ }^{12}$ Christian inveiglement in structuring this coercive world was epitomized in the project of slavery - the centrepiece of capitalism - which Mbembe describes as 'the emergence of the Black Man as human-merchandise, human-metal, human money. ${ }^{\prime 3}$ The growing awareness in the Church of Christian complicity in the plunder of nature to create this capitalist world is as grave as it is salutary and timely. ${ }^{14}$

11 Quoted from There is Only One World, the epilogue of Achille Mbembe's, Critique of Black Reason (Johannesburg: Wits University Press, 2017), published at The Con Magazine: There is Only One World, [Online] Available: http://www.theconmag. co.za/2017/07/19/there-is-only-one-world/ [Accessed: 24 August 2017].

12 There is Only One World [Accessed: 24 August 2017].

13 There is Only One World [Accessed: 24 August 2017].

14 See for example, Wendell Berry, who holds that 'modern Christianity has become willy-nilly the religion of the state and the economic status quo. Because it has been so exclusively dedicated to incanting anaemic souls into Heaven, it has been made the tool of much earthly villainy. It has, for the most part, stood silently by while a predatory economy has ravaged the world, destroyed its natural beauty and health, divided and plundered its human communities and households. It has flown the flag and chanted the slogans of empire [...] It has admired Caesar and comforted him in his depredations and defaults. But in its de facto alliance with Caesar, Christianity connives directly with the murder of Creation. For in these days, Caesar is no longer a mere destroyer of armies, cities and nations. He is a contradictor of the fundamental miracle of life. A part 
Small wonder then, that in 2017 Christians, Christian congregations, and the Church in general, stand gravely in question - a predicament that is borne vicariously by Christians of all traditions. In other words, questionable Christian witness in North America or South Africa in 2017 arises from historical transgressions that distorted the grammar of God's Kingdom, transgressions vicariously shared by all who follow Jesus as Messiah. In too many ways local congregations have conformed to Empire, and compromised the norms of Jesus' Beatitudes, of his Sermon on the Mount, in too many reincarnations of Constantine's concordat - that recurring abusive marriage between the Church and coercive hegemonic powers.

The furore in June 2017 in the United States, as 5000 Southern Baptist Convention leaders initially refused to distance themselves from the white supremacist alternative right and the overt violence of Donald Trump's 'transgressive politics,' is one example of this questionable Christian witness. ${ }^{15}$ Similarly, questions arise in South Africa. For example, President Jacob Zuma has been encouraged to 'preach' in mass congregations. ${ }^{16}$ With signature cynicism, Zuma has equated the birth of the ANC to the advent of Jesus Christ, has called on Christians to endorse his leadership or his party's mandate, and has warned South African churches that Christians should pray and leave politics to the government. In response, vocal Church leaders have issued counter-warnings to Zuma in language employing almost identical Constantinian assumptions of power and metaphors of coercion, rallying South African Christians to 'active engagement' by

of the normal practice of his power is his willingness to destroy the world. He prays, he says, and churches everywhere compliantly pray with him. But he is praying to a God whose works he is prepared at any moment to destroy. What could be more wicked than that, or more mad?' So, Wendell Berry, Sex, Economy, Freedom and Community: Eight Essays (New York: Pantheon Books, 1992), 114-115.

15 This is Kate Shellnut's adjective in 'Southern Baptists Approve Alternate Resolution against the Alt-right,' Christianity Today, 14 June 2017. [Online] Available: http://www. christianitytoday.com/news/2017/june/southern-baptists-vote-resolution-against-alt-right-sbc17.html [Accessed: 15 June 2017].

16 See, 'Mail \& Guardian, 6 January 2017, Zuma Takes Soweto to Church as he compares the ANC to Jesus Christ.' [Online] Available: https://mg.co.za/article/2017-01-06-zuma-takessoweto-to-church-as-he-compares-the-anc-to-jesus-christ [Accessed: 15 June 2017]. For Zuma's 14 April 2017 'sermons' in Durban and Johannesburg see, 'Eyewitness News: Zuma Skips Politics, Asks for Congregants to Pray for South Africa.' [Online] Available: http://ewn. co.za/2017/04/14/zuma-skips-politics-asks-congregants-to-pray-for-sa [Accessed: 15 June 2016]. 
'all means possible' so that 'the project to capture the state and its key institutions are terminated at all levels of Government and operation.' ${ }^{17}$

The current context of Christianity in North America and South Africa perpetuates the fifteen hundred-year Constantinian temptation of Christians and congregations to arrogate to themselves God's action of transforming the world. What might be seen as a Constantinian objectsubject confusion in the grammar of God's Kingdom once again tempts Christian leaders to jockey for magisterial influence or control, in the hope of leveraging 'Christian truth' onto society from an imagined 'Christian' centre of power. Succumbing to this temptation in any age has prevented local congregations from modelling Jesus' ethics from below, as in Christ's metaphors of salt in a meal or light in the darkness (Matt 5:13-14). ${ }^{18}$

As key South African organs of the State appear to have been captured by nefarious transnational principalities ${ }^{19}$ there are remarkable similarities between the contexts of Christian witness and worship in South Africa and North America - the Zuma and Trump administrations alike are aloof, centralizing hegemonies, indifferent, even disdainful of the weakest members of society and the common good. ${ }^{20}$ The numbers of men who

17 My emphasis. So, The Citizen, 'Don't Make an Enemy of the Church, Pityana Warns Zuma,' [Online] Available: http://citizen.co.za/news/news-national/1365271/dont-make-moreenemies-pityana-warns-zuma/ [Accessed: 15 June 2017]. Also, 'Church in Action: National Church Leaders Forum Makes Strong Call on Anc to Act.' [Online] Available: http:// ngkok.co.za/kennisg/201715/2017-04-20\%20SACC-Statement-on-State-of-South-Africa.pdf [Accessed: 15 June 2017].

18 Perpetuation of the Constantinian temptation is the subject of Stanley Hauerwas' 1994 essay, 'What Could It Mean for the Church to be Christ's Body? A Question without a Clear Answer,' published in his In Good Company: The Church as Polis (Notre Dame, IND: University of Notre Dame Press, 1995), pp. 19-32.

19 See the Report of the Public Protector, Thuli Madonsela, 'State of Capture,' (Cape Town: Office of the Public Protector, Report no. 6 2016/2017). [Online] Available: http://cdn.24. co.za/files/Cms/General/d/4666/3f63a8b78d2b495d88f10ed060997f76.pdf Multidisciplinery analysis of state capture can be found in Mark Swilling, ed., 'Betrayal of the Promise: How South Africa Is Being Stolen,' in State Capacity Research Project (Stellenbosch: Centre for Complex Systems in Transition, 2017). A journalistic overview is Rajeny Munusamy's 'Betrayal of the Promise: The Anatomy of State of State Capture,' Daily Maverick, 26 May 2017, https://www.dailymaverick.co.za/article/2017-05-26-betrayal-of-the-promise-the-anatomy-ofstate-capture/ [Accessed: 18 July 2017).

20 The common good is the politics of wellbeing - local and national economics that foster wellness in the natural environment and among all people, especially the most vulnerable members of society, irrespective of identity, culture or religion. The earliest source of this idea in Judaism and Christianity is the Deuteronomistic law of love - 
rape in everyday South Africa ${ }^{21}$ and the numbers of U.S. commissioned drone bombs, destroying Middle Eastern lives and communities in 'remote' attacks, ${ }^{22}$ illustrate not only South African and U.S. State indifference to the common good, but a corresponding need for more 'salt and light' from South African and North American Christian congregations. Jesus' Gospel invitation remains, for local churches to embody the grammar of God's Kingdom through a politics that germinates social healing and transformation, as a sign of the new creation.

In such a milieu, questions that decisively shaped the church struggle in South Africa under apartheid need to be asked again with renewed urgency: How are South African Christians to follow Christ in a prophetic witness and presence that undoes social injustice and exercises the common good, in the tradition of Christ and the prophetic communities of the early church? ${ }^{23}$ The related question of whether coercion and violence have any place in Christian discipleship, in the face of injustice, also has fresh contemporary relevance. ${ }^{24}$ As it happens, such questions about how Jesus'

love of God, love of neighbour, and honour of creation, which is summed up in the Old Testament as God's peace or shalom. In the Gospels Jesus assumes this common good in his re-affirmation of the two greatest Deuteronomic commandments. For a probing exposition see Perry Yoder, Shalom: God's Word for Salvation, Justice \& Peace (Nappanee, IN: Evangel Publishers, 1987) and Ronald Sider, The (Un)Common Good: How the Gospel Brings Hope to a World Divided (Grand Rapids, MI: Brazos Press, 2015).

21 An introduction to this crisis is Gordon, Sarah Frances, and Anthony Collins. 'We face rape. We face all things': Understandings of gender-based violence amongst female students at a South African university. African Safety Promotion: A Journal of Injury and Violence Prevention 11, no. 2 (2013): 93-106.

22 A recent investigation is Chris Woods, Sudden Justice: America's Secret Drone Wars (Oxford: Oxford University Press, 2015).

23 The Greek verb prophèteúō means 'to prophesy [...] to proclaim or testify [...] to be an oracle prophet.' See Gerhard Kittel and Gerhard Friedrich, eds., Theological Dictionary of the New Testament (TNDT), trans. Geoffrey Bromley (Grand Rapids, MI: Eerdmans, 1985), 953. This word relates to the verb martyréo - 'to bear witness' - whose noun form martýs - 'witness' - is the etymological root for the English word 'martyr' (John 15:27; 18:37 cf. Matthew 24:14; Acts 22:15 etc.) See Kittel and Friedrich, TNDT, 564-566. This biblical theology understands the 'prophetic' as actions taken by a prophet with her or his community in obedience to God, to achieve justice for the poor or marginalised, for the common good, for which prophetic communities are oppressed by unjust authorities.

24 For background on how this question was framed under Apartheid see Charles Villa-Vicencio, Theology and Violence: The South African Debate (Grand Rapids, MI: Eerdmans, 1988). 
ethics or politics might prophetically transform an economy of injustice to champion the common good, were at the heart of the medieval movement that birthed the Radical Reformation and the first Anabaptists' noncompliance with the magisterial reforms of Luther, Zwingli and Calvin in the $16^{\text {th }}$ Century. ${ }^{25}$

The purpose of this study is a retelling of the birth of the Anabaptist Radical Reformation in solemn commemoration of the five hundredth anniversary of the Reformation-schism. While events will be narrated as succinctly as possible, the spirit in which they are told necessarily remains sombre, because broken communion among Christians which arose during the Reformation has taken half a millennium to begin to repair. ${ }^{26}$ In the Christian posture of penitence then, this essay briefly recounts the emergence of counter-hegemonic local congregations in the late medieval movement of Germanic Southern Europe, out of which George Blaurock (c.1491-1529), ${ }^{27}$ Conrad Grebel (1498-1526), Felix Mantz (1498-1527), Margret Hottinger (d.1530), Michael Sattler (1490-20 May 1527) and other Radical Reformers questioned and then circumvented Huldrych Zwingli's evangelical reform of Zurich between 1524 and 1528. These Radical Reformers might be understood to have revived the pacifist tradition of local congregations in the pre-Nicaean era. ${ }^{28}$ They rejected any form of coercion in their ministries, which, with some infamous exceptions, became a defining characteristic of most Anabaptist churches. ${ }^{29}$ In this,

25 I thank John de Gruchy for his affirming response to a first draft of this research, and for encouraging me to emphasize that the history of the Radical Reformation predated Luther. An overview of medieval radical reform antecedents to the Anabaptists is John Driver, Radical Faith: An Alternative History of the Christian Church (Kitchener, Ontario: Pandora Press, 1999), pp. 129-178.

26 Lutherans and Mennonites finally reconciled in a service of repentance at Stuttgart in 2010, and the process of reconciliation continues. See, Jeremy M. Bergen, 'Lutheran Repentance at Stuttgart and Mennonite Ecclesial Identity,' $M Q R$ vol. 88, no. 3 (July 2012).

27 This study cites the biographical dates of only the Radical Reformers.

28 A history of the Church's ante-Nicaean stance towards war is Jean-Michel Hornus, It is Not Lawful for me to Fight: Early Christian Attitudes to War, Violence, and the State, trans. Alan Kreider and Oliver Coburn (Eugene, Oregon: Wipf \& Stock, 2009).

29 A well-known deviation from Anabaptist pacifism was by Melchior Hoffman and his followers in Münster in 1534. This and other deviations are exceptions to the ubiquitous pacifist tradition of the Swiss Brethren, the Mennonites, the Hutterites and the Amish. For an introduction to Melchiorite Anabaptism, see James Stayer, Anabaptists and the Sword (Lawrence, Kan: Coronado Press, 1976), 227-280. 
Anabaptists came into increasing disagreement with Luther, Zwingli and Calvin who increasingly retained and developed theological warrants for Church-State conciliation in their ecclesiologies. ${ }^{30}$

In other words, this essay recalls historical evidence of the origins of an ethics of peace-making in the sixteenth century, through the evangelism and spread of early Radical Reformers' local congregations. Simultaneously, the discussion aims to demonstrate that the very first Anabaptist gatherings in Swiss and German speaking Europe were recognisably prophetic in character. That is, the distinct politics of Anabaptist congregations embodied prophetic alternatives to the territorial Reformers' growing association with coercive powers in Europe's emerging secular nation states. Finally, discussion will return with a leap of resonance to Christian discipleship in local congregations in South Africa today. The recurring history of Church capture in a Constantinian concordat with secular powers, not least with the current neo-colonial and neoliberal brokers of self-interest, ${ }^{31}$ invites South Africans of all denominations to reconsider the New Testament grammar of God's transforming Kingdom, and to reimagine and reanimate local congregations in South Africa through the cruciform ethics of Jesus Christ. The paper will conclude by heuristically imagining local South African churches in conversation with Anabaptist traditions - congregations which David Bosch once imagined as 'God's experimental garden,' or God's 'alternative community'32 - local churches engaged in sacrificial restitution for a beleaguered creation, through an alternative economics of wellbeing, and in counter-hegemonic practices of mission, in solidarity with the poor, the marginalized, the disabled, the orphan, the homeless, the unemployed and the refugee.

30 Luther's Invocavit sermons at Wittenberg in 1522 and Zwingli's public disputation about the Mass in October 1523 marked the beginning of the territorial Reformers' concordat with the Princes, in whose interests 'they backed away from the radical social and political implications of their arguments and revised their theological programs in the interest of social stability and their own political survival.' So, So John D. Roth, 'Recent Currents in the Historiography of the Radical Reformation,' Church History, vol. 71, no. 3 (2002): 538.

31 On the roots of the ANC's pre-1994 capture to a neoliberal economic future in South Africa see Carolyn Bassett's 'neoliberal South Africa After Apartheid: A Better Life Betrayed,' Canadian Dimension, vol. 48, no. 2 (Mar/Apr2014).

32 So, Cobus Van Wyngaard, 'The Church as Alternative Community and the Struggle for Justice in the Work of David Bosch,' Dutch Reformed Theological Journal, vol. 54, no. 3-4 (September, December 2013): 1-11. 


\section{Which way to apprehend 'new streams' on the Rhine and Danube?}

Four caveats about retelling the events of the Radical Reformation in the South African context are necessary before the brief exposition to follow. The first caveat concerns the continuity of Anabaptism with late-medieval theologies and spiritualties that embodied a similar challenge to abuses in Christendom. Peter Chelcicky and the Czech Brethren's rejection of coercion and war, and their commitment to the poor as a challenge to violence and opulence in the Church of the late $1400 \mathrm{~s},{ }^{33}$ and the simultaneous advent of the evangelist or illuminist movements in the Roman Church in France, Spain and Italy, exemplified in the ministry of Juan de Valdez, ${ }^{34}$ are the two pertinent continental expressions of radical reform which anticipated the Reformation in Germanic lands.

A second caveat is important because residual ignorance about 'Anabaptists' persists in South Africa, for two reasons. Anabaptist congregations, missionary work and ecumenical presence are almost unknown to South African Christians, because World Mennonite Conference churches and their agencies were barred from ministry within South Africa for half a century by the apartheid regime, and the World Mennonite Conference decided not to plant Mennonite or Brethren congregations in South Africa after $1994 .{ }^{35}$ For this reason, South African Christians tend to hear the 'Baptist' in 'Anabaptist' and assume that Anabaptists are identical with British Baptists, North American Baptists, or South African Baptists. There is as yet limited understanding in South Africa of the Mennonite, Hutterite and Swiss Brethren traditions, with their direct genealogical roots to the medieval era prior to the Reformation in Continental Europe. ${ }^{36}$

33 A good starting place in the literature is Peter Brock, The Political and Social Doctrines of the Unity of the Czech Brethren (The Hague: Mouton and Co., 1957).

34 An early overview in the literature is José de Nieto, Juan de Valdés and the Origins of the Spanish and Italian Reformation (Geneva: Libraire Doz, 1970).

35 See Andrew G. Suderman, 'The Mennonite Experience in South Africa: An Alternative Imagination,' Mennonite Quarterly Review, vol. 89 (2015): 253-274. For an introduction to the regional story of Anabaptist presence in Southern Africa see Allen J. Goddard, 'Beginnings, the Ending and Africa's Century of Anabaptist Witness, in Between,' in Isobel Phiri and Dietrich Werner et. al., Anthology of African Christianity (Pietermaritzburg: Cluster Publications, 2016).

36 Anabaptista had been a pejorative term for a millennium, since Emperor Justinian criminalized adult baptism, making it a heresy on a par with anti-Trinitarianism, and 
A third caveat concerns the method employed in this research. There had been a 'rich and nuanced' outpouring of historiography since Harold S. Bender's influential international paper titled The Anabaptist Vision in $1943,{ }^{37}$ which has reintegrated 'Anabaptists into the broader drama of the Reformation and into church history more generally. ${ }^{38}$ Increasing openness by mainstream continental and English-speaking historiographers to study Anabaptist contributions to the Reformation was greatly encouraged by George Williams' monograph, The Radical Reformation, published in 1962. ${ }^{39}$ Subsequent scholarship by Anabaptist historians has fruitfully problematized Bender's unhelpful assumption that there was a homogeneous Anabaptist movement since $1524 .{ }^{40}$ Further revisionist historiography demonstrated that Anabaptist origins are complex in their spontaneous 'polygenesis' in the Swiss, German and nether regions of Charles V's Holy Roman Empire and must be understood in relation to contextual historical developments like the theological divergence from Martin Luther of Andreas Carlstadt and Thomas Müntzer, ${ }^{41}$ the Peasants War, anticlericalism and the like. ${ }^{42}$

Therefore, the research presented in this essay adopts this polygenetic understanding of the Anabaptist origins and utilizes Brad Gregory's helpful approach of discarding the often-circuitous reasoning of the 'hermeneutics of suspicion' when re-reading the primary sources. ${ }^{43}$

punishable by death. See Arnold Snyder, Anabaptist History and Theology: Abridged Student Edition (Kitchener, Ontario: Pandora Press, 1995), 1-3.

37 Bender's address was published simultaneously in North America as Harold S. Bender, 'The Anabaptist Vision,' Church History 13 (Mar. 1944): 3-24, and Harold S. Bender, 'The Anabaptist Vision,' The Mennonite Quarterly Review vol. 18 (Apr. 1944): 67-8.

38 This is Roth's thesis. Roth presents a lucid overview of two revisionist movements in Anabaptist historiography up until 2000. John Roth, 'Recent Currents ', pp. 523-534.

39 George H. Williams, The Radical Reformation, 3d ed. (Kirksville, Mo.: Truman State University Press, 2000).

40 Prominent in this revision of Anabaptist historiography was James M. Stayer, Werner O. Packull, and Klaus Depperman's essay, 'From Monogenesis to Polygenesis: The Historical Discussion of Anabaptist Origins,' The Mennonite Quarterly Review, 49 (1975): 83-12.

41 So, Arnold Snyder, 'The Emergence of Radical Reform,' in Anabaptist History and Theology.

42 So, John Roth, 'Recent Currents', pp. 525-535.

43 Brad Gregory, Salvation at Stake: Christian Martyrdom in Early Modern Europe. (Harvard: Harvard University Press, 1999). 
Gregory's employment of Paul Ricoeur's 'second naiveté,' that is, reading the sources at face value and accepting Anabaptists' costly adherence to non-violence (notwithstanding the exceptions already noted) without suspecting the Radical Reformers of hidden mystical, psychological, ideological or political agendas. ${ }^{44}$

A final caveat, before commencing this commemorative reconstruction of the German Radical Reformation, is that this research might be mistaken as a binary narrative, a kind of Anabaptists-versus-the-rest, approach, in the service of a moralistic hagiography. ${ }^{45}$ Such a retelling would be fallacious, and would likely reopen old wounds of the Reformation schism - the opposite of what this research intends. As has been stated above, early events of the Radical Reformation are retold here firstly as a sombre commemoration. They are retold for the first time by in a South African publication, because Anabaptist history and ecclesiology have been so effectively suppressed in South Africa so that little of the Anabaptist tradition is generally known in this part of the world. My hope is that the relevance of this essay's goal, to perceive a prophetic theme within the Radical Reformation, will become evident as part of my aim in the introduction and conclusion, to revive renewed commitment to the local church. May what emerges also be a commemoration for the purpose of dialogue, restoration, healing and communion.

What follows then is a sketch of the theological, ethical tide in late medieval radical Christian discipleship that evoked the sudden appearance of secret Anabaptist congregations in independent rural Swiss cantons and citystates and South German principalities of the Holy Roman Empire after 1524. In the spirit of Ricoeur's second naiveté, just a few primary sources will be revisited to apprehend this new expression of 'radical medieval Christianity' in the Radical Reformers' missionary activities around Zurich, along the Rhine, to southern Germany and along the Danube into the Tirol, Bohemia and Moravia respectively, from 1524, to the circulation

44 Roth shows how Gregory is indebted to Paul Ricoeur, Essays on Biblical Interpretation, ed. Lewis S. Mudge (Philadelphia: Fortress, 1980). So, Roth, 'Recent Currents', p. 535.

45 Philippe Denis' helpful comments after reading a first draft of this research have been apt for a commemoration as grave as this anniversary of the Reformation-schism. For an introduction to Denis' holistic contribution to commemorative history, see Helené van Tonder, 'Interview With Philippe Denis,' Acta Theologica 35:1 (2015):1-9. 
of the Schleitheim Articles during 1527. The focus will be on the polity, theology and missionary activities of the first Anabaptists to see if they embodied a prophetic and apostolic character.

\section{Secular powers, emerging capitalism and the politics of ecclesiastical reform}

By the early 1500s the Renaissance's new engines of power were increasingly disrupting the hegemony of the Roman Church in its millennial concordat with continental monarchs and emperors. The political dominance of Rome to regulate every aspect of European society since the reforming popes of the twelfth century had been weakened by the Avignon papacy (1309-1377) and was almost shattered by the Great Schism (1379-1417). ${ }^{46}$ Europe's emerging and ebullient national monarchies in France, Spain and England and the possibility of a new secular hegemony with the election of Charles V as the fifth Holy Roman Emperor in 1519, further undermined the authority of the Church. Thus, any study of the Reformation has to take seriously a complex nexus of relationships between the Reformers, the immediate political and economic interests of their powerful local rulers who were sponsored by absolute monarchs, and a rapidly shifting economic centre of power from rural feudalism to urban mercantile capitalism:

All kings, princes, and town councils considering an evangelical ecclesiastical reform had to weigh the political consequences of allowing reform to take place. Often a choice for the Reformation came to rest on questions of political alignments and possibilities rather than on justification by grace through faith or theological issues as such. The consequences of failing to win over any political authorities to one's point of view were devastating. ${ }^{47}$

Sixteenth Century Christendom's enmeshment in this maelstrom of transforming political and economic power is pertinent for the purpose of this study. As has already been seen, no small part of the socio-economic revolution underway in late medievalism was the recurrence of prophetic

\footnotetext{
46 Detailed analysis is widely published. My synopsis follows Snyder, Anabaptist History and Theology, pp. 9-19.

47 Snyder, Anabaptist History and Theology, p. 10.
} 
challenges to corrupt Christendom in fresh expressions of radical reforms, along the lines of movements initiated by Peter Celcicky and Juan de Valdez. The remaining historical reconstruction will sketch the earliest Radical Reformers' challenge to Zwingli in Zurich between 1524 and 1528, as evidence of this late medieval prophetic movement because Anabaptists similarly reanimated local congregations to practise an alternative politics of church.

\section{Reformation as apostolic restoration, from the underside}

The historical impetus for radical reform in Swiss and German lands occurred simultaneously and reciprocally during 1524 in the heart of Zurich, in Zwingli's reforming congregations and in rural parishes surrounding Zurich, especially to the north along the Rhine, in the Black Forest region near Waldshut, and eastwards towards Lake Constance and the Danube. ${ }^{48}$ Concurring social and political developments in southern Germany are crucial to understand the social engagement of the first Anabaptist congregations, so this rural German context will now be introduced.

From 23 June 1524, farming peasants in the Black Forest who were requisitioned as cheap labourers on vast estates belonging to the monasteries began to withdraw their labour in protest, evoking censure from bishops in league Archduke Ferdinand of Austria and his Innsbruck battalions. Coercion of the peasants escalated into the rural conflagration known as The Peasants War (1524-1526), a conflict which spread southwards into central Germany in which 100000 people perished! ${ }^{49}$ Balthasar Hubmaier (c. 1480-10 March 1528) who had earned a doctorate in theology under Johannes Eck and was now a priest at Waldshut, was to become one of many Anabaptists to empathize with the peasant struggle. In 1524, Hubmaier, who had implemented Zwinglian reforms and who had given refuge to peasant resistance leaders, was declared a heretic and had to flee the possibility

48 Unless I provide supplementary citations, all the paragraphs in this subsection draw on Snyder, Anabaptist History and Theology, pp. 45-52.

49 The human toll of this war can be better imagined when one considers that Strasbourg, the biggest city of Southern Germany at the time, had 20000 inhabitants. So, Snyder, Anabaptist History and Theology, p. 106. 
of capture by Habsburg troops to the free city of Schaffhausen - the first centre of the Peasants' War. ${ }^{50}$ Here the peasants enlisted Hubmaier's help to pen their 12 Articles of representations to the Habsburg authorities.

Meanwhile, in the Great Minster of Zurich from early 1524, Zwingli, who since 1520 had been preaching an end to usury and ecclesiastical celibacy and that the sacraments could not communicate God's grace by mere administration, was censured and silenced. The Zurich Council, which had supported Zwingli's break from the Roman Church in 1522, appointing him as city preacher, now feared the resonance of Zwingli's administrative reforms with 'tithe unrest' in the villages around Zurich, ${ }^{51}$ and with peasant demands for economic reform to the north of the Rhine. Zurich councillors wanted to avoid an incursion of German peasant insurrection into the Swiss-German confederation.

From October 1523 priests and deacons in Zurich, who were part of Zwingli's reform, like Grebel and Mantz, and sympathetic visitors who joined Zwingli from the surrounding countryside, like Wilhelm Reublin (1484-1559) and Johannes Brőtli (1494-1528), had met with Zwingli on a few occasions to request permission to form churches that might appoint their own councils of the 'prayerfully devout'. ${ }^{52}$ This group had been disappointed in October 1523 during the second Zurich Disputation, on the Mass, when Zwingli did a theological about-turn, towing the line of the Zurich Council, and refrained from instituting a memorial Lord's Supper. ${ }^{53}$ By mid-1524, home Bible study meetings of Mantz and Grebel in Zurich added the matter of adult baptism to a list of proposed reforms for their congregations. In September 1524 they delayed their presentation of child candidates for baptism while waiting for replies to letters they had sent to

50 Ferdinand could not afford to despatch soldiers, so Waldshut welcomed Hubmaier back to further reform the churches in October 1525. See C. Arnold Snyder, 'The Birth and Evolution of Swiss Anabaptism (1520-1530),' Mennonite Quarterly Review, vol. 80 (2006): 510, 529-530.

51 Snyder, 'The Birth and Evolution of Swiss Anabaptism', pp. 514-515.

52 Snyder provides more analysis on whether the Radical Reformers were separatist from the beginning, or whether they wanted independent congregations with the permission of the political authorities. So, 'The Birth and Evolution of Swiss Anabaptism', pp. 520523.

53 Cornelius J. Dyck, Introduction to Mennonite History (Scottdale, Pen: Herald Press, 1993), p. 37. 
Luther, Andreas Carlstadt and Thomas Müntzer. In his letter to Müntzer, Conrad Grebel had also voiced the Anabaptists' first stated commitment to non-violence, arguing that disciples 'must reach the fatherland or eternal rest not by slaying the physical but the spiritual. They use neither worldly sword nor war, since killing has ceased with them entirely. ${ }^{54}$

The public disputation before the Zurich Council in January 1525 sparked Zurich's imagination. Grebel and Mantz laid out a theology of baptism 'given to believers to whom the gospel had been previously preached, who have understood it, and who thereupon requested baptism for themselves, and killing the old Adam, desired to live a new life. ${ }^{55}$ Daring to imagine local congregations constituted by adult baptism, set free from the civic concordat which had regulated Church-State relations since Constantine - congregations governed exclusively by obedience to the 'outer witness' of Scripture and 'inner witness' of Holy Spirit - was revolutionary. This ecclesiastical subversion and popular support for vernacular Bible studies among the craftsman, artisans and peasants in Zurich, elicited swift, coercive reactions from the Zurich Council. ${ }^{56}$

Zwingli was required to cease all public disputations with 'dissident' priests or deacons regarding the mass or baptism. On 18 January 1525, the Council ruled that parents of unbaptized infants, like Conrad Grebel, whose infant daughter remained unbaptized, would face exile from Zurich if the children's names failed to appear in the baptismal registers within eight days. The Council also ordered all home gatherings to cease.

Zwingli's compliance with the Council's coercion was a defining moment for Grebel, Mantz, Reublin, Brőtli, who having already given up their Roman Catholic licences, now felt compelled to distance themselves from Evangelical reform. On the evening of 21 January 1525 they met in Felix Mantz' mother's home in secret 'until dread [Angst] began to come

54 Snyder quoting a source of Grebel's letter to Müntzer, Anabaptist History and Theology, p. 51. For background to the letter, see Snyder, 'The Birth and Evolution of Swiss Anabaptism', p. 528.

55 Snyder's translation of Bullinger's first-hand account of the disputation. So, Anabaptist History and Theology, p. 48.

56 Snyder, 'The Birth and Evolution of Swiss Anabaptism': 504-505. 
over them, yea, they were pressed in their hearts. ${ }^{57}$ After a time of prayer George Blaurock asked Grebel to baptise him, 'for the sake of God, with true Christian baptism upon his faith and knowledge [...] since at that time there was no ordained deacon to perform such work. ${ }^{58}$ In what followed all members present underwent the first adult baptisms documented since the ante-Nicaean era.

Blaurock, Mantz and Grebel immediately left the city and organized the first baptizing house meetings three kilometres south of Zurich, in the village of Zollikon, where thirty-five adults were baptized. From here the baptizers took refuge in country parishes south, north and east. In the village of Appenzell antipathy towards the reactionary Roman Church of rural Swiss cantons further south made weavers, farmers, trade union leaders and peasants sympathetic to the message of repentance and baptism.

Grebel travelled northeast to St Gallen where the reform movement was growing exponentially in the wake of that council's censorship of Johan Kessler's preaching. ${ }^{59}$ It was reported that Grebel baptized 300 people in the Sitter River on Palm Sunday - 15 March $1525 .{ }^{60}$ Within one week of the first Zurich baptisms Reublin and Brötlil were baptizing to the northwest across the Rhine, at Hallau and Waldshut, where they met Humbaier, now returned to Waldshut from Schaffhausen. ${ }^{61}$ On Easter Day Reublin baptized Hubmaier, along with all sixty adults in his congregation and Hubmaier went on to baptize 300 adults in house meetings around Waldshut in the following weeks.

The increasing momentum of Swiss Anabaptist missionary preaching and planting of re-baptizing house churches was evoked by increasingly coercive conciliar action - deportation orders issued in joint authority by

57 From an old Hutterite retelling of the event in George H. Williams, ed., Spiritual and Anabaptist Writers (Philadelphia: Westminster Press, 1957), pp. 43-44.

58 Williams, Spiritual and Anabaptist Writers, p. 44.

59 Wolfgang Uliman took over from Kessler with 'lay readings' twice a week to more than 1000 weavers and other guild members, in the Butcher's Hall. In March 1525 the council acquiesced to popular demand in the town and allowed the readings to proceed in the St Lawrence Church. So, Snyder, 'The Birth and Evolution of Swiss Anabaptism', pp. 564-565.

60 Snyder, 'The Birth and Evolution of Swiss Anabaptism', p. 567.

61 Snyder, 'The Birth and Evolution of Swiss Anabaptism', p. 550. 
Church and State immediately re-classified them as 'aliens' or non-citizens. The Radical Reformers' accepted their new pariah status and soon regarded themselves as neither Catholic nor Evangelical. They saw themselves simply as 'brethren'.

In April, after Grebel's departure from St Gallen, another well-loved Anabaptist preacher arrived, Bolt Eberli, who was captured by Austrian troops nearby Schwyz and burned on the village square - the first Swiss Anabaptist martyr. ${ }^{62}$ In mid-May of 1525 Luther took the side of his Habsburg protectors when the Peasants' War came to a head in Thuringia, at Frankenhausen. Luther called on anyone supporting the army of Phillip of Hesse to 'smite, slay, and stab, secretly or openly, remembering that nothing can be more poisonous, hurtful, or devilish than a rebel. ${ }^{63}$ Through the summer and autumn of 1525 the Radical Reformers' missionary activities in the Grüningen area were curtailed by the conciliar decrees of Zwingli and the Council. Further conciliar decrees between Zwingli, Vadian - the Burgermeister of St Gallen, and the Council of Bern, criminalized Anabaptists and those who gave them refuge.

In July 1525 Hubmaier had published a tract, Summary of the Entire Christian Life, the first public statement of Anabaptist ecclesiology - the local congregation founded on repentance, belief in the Gospel, baptism, and public proclamation and the Lord's Supper as a memorial meal. ${ }^{64} \mathrm{~A}$ week later Hubmaier published his On the Christian Baptism of Believers, a clearly stated biblical theology of baptism, as well as an ecclesiology of the church of adult baptized disciples. ${ }^{65}$ Tensions came to a climax between Zwingli and his former priests at the Third Zurich Disputation, on Baptism, from 5-8 November 1525.

Zwingli and the Council detained Mantz, Grebel, Blaurock, Margret Hottinger of Zollikon and others for being Anabaptists. Among them was a sympathizer to the Anabaptists, Michael Sattler (1490-21 May 1527) of

62 Unless otherwise noted, this and the next two paragraphs follow Snyder, 'The Birth and Evolution of Swiss Anabaptism', pp. 570-585.

63 Robert C. Shultz, ed., The Christian in Society, vol. 46 of Luther's Works, ed., Helmut T. Lehmann (Philadelphia: Fortress Press, 1967), p. 1950.

64 For Snyder's analysis, see 'The Birth and Evolution of Swiss Anabaptism', pp. 559-561.

65 So, Snyder, 'The Birth and Evolution of Swiss Anabaptism', pp. 561-562. 
Stauffer, a former monk of St Peter's of the Black Forest in the Breisgau near Freiburg, who was now married and learning the weavers' trade among the Anabaptists of the Waldshut-Hallau area. ${ }^{66}$ On 18 November as Mantz, Grebel and Blaurock were sentenced to the Wellenberg Tower in Zurich, for refusing to recant, Sattler vowed to abjure Anabaptism and left Zurich, returning to his wife Margaret and a group of Anabaptist weavers in Bülach near Hallau. ${ }^{67}$ In December, Hubmaier, who had fled an impending Habsburg siege of Waldshut, was captured in Zurich and recanted. He then publically recanted his recantation in the Great Minster on 29 December. Hubmaier was imprisoned and tortured in the Wellenberg Tower.

Increasing persecution from Reformers and reactionary Habsburg princes alike gave a new meaning to the late-medieval theology of total resignation to God, or gelassenheit, and provoked the spread of the baptizing movement throughout 1526. ${ }^{68}$ Grebel, Mantz, Blaurock and others escaped prison in March and went in different directions. Grebel was ill and died within weeks in the Glattfelden area. Mantz and Blaurock returned to Grüningen and Margret Hottinger to St Gallen. After a private recantation and a vow never to return to Zurich, Hubmaier fled to Augsburg in April and then on to Nikolsburg in Moravia where he established an Anabaptist church with the consent of the Lords of Lichtenstein. By June, Michael Sattler had been re-baptized and was moving gradually through the Black Forest, avoiding capture, to Strasbourg where he baptized in neighbouring Lahr; at Strasbourg, he pleaded with city reformers, Bucer and Capito, for the release of Anabaptist prisoners. ${ }^{69}$

Zwingli's suppression of the first generation of Anabaptists culminated on 19 November 1526 in the recapture and imprisonment of Mantz, Blaurock, and others, and a decree making the act of re-baptizing another punishable

66 With regard to the date of Sattler's conversion, I follow Snyder's interpretation of the sources, rather than Yoder's. For Snyder's revision see his 'Revolution and the Swiss Brethren: The Case of Michael Sattler,' Church History 50:3 (1980): 276-287.

67 So, Snyder, 'The Case of Michael Sattler', p. 285.

68 The history of 'gelassenheit' from medieval divines like Meister Eckhart through the Anabaptists, to Heidegger is complex. For more on how Anabaptists appropriated the concept, see Arnold Snyder, 'Gelassenheit and Anabaptist Spirituality: Balthasar Hubmaier's Catechism of 1526,' Conrad Grebel Review, 9:1 (1991).

69 Snyder, 'The Case of Michael Sattler', p. 277. 
by drowning, and receipt of believers' baptism punishable by fines or imprisonment. On 5 January 1527, Mantz became the first Anabaptist martyr in Zurich when he was bound and thrown into Zurich's Limmat River. $^{70}$

This first year of ministry by re-baptizers is regarded as the birth of the Radical Reformation because Anabaptists may be understood to have remembered the New Testament grammar of God's Kingdom, the church as object of God's transforming action. Anabaptists may also be understood to have restored a politics of local congregational life which had not been seen since the ante-Nicaean era of Roman imperial persecution.

\section{A prophetic germinal in the Radical Reformation}

Discussion now returns to the primary theme of this study - a recognizably prophetic stream within late medieval reform, and evidence for continuity of this prophetic Christianity in the work of the Radical Reformers. Zwingli's periodic adaptation of his theology to suit a reactionary Zurich Council and Luther's about-turn on the peasants at Frankenhausen can be seen as the survival into the Reformation era of the fourteen hundred year Constantinian concordat between Church and State. Evangelical reformers were quickly adopting the coercive posture of their former Roman Catholic superiors so that reform and counter-reform soon became mirror images of each other in 'two church-state systems. ${ }^{71}$ Sixteenth century Lutheran and Catholic principalities may have prided themselves in antithetical theologies, hymnbooks, church hierarchies and even architectural styles, but Catholics and Evangelicals were indistinguishable in their prior political and economic commitments - to uphold the medieval status quo by closely aligning themselves with powerful aristocratic elites at the expense of the poor masses. This essentially Constantinian character of Christendom in the reforming and counter-reforming territories of German-speaking Europe in the 1520 s explains why the first Anabaptists were so quickly

70 Eyewitness accounts of most sixteenth century Anabaptist martyrdoms are preserved in Thielman J. van Braght's The Bloody Theatre or Martyrs' Mirror, (1660) trans. Joseph Sohm (Scottdale, Pa: Herald Press, 1972).

71 This is John Howard Yoder's term in John Howard Yoder, ed., The Legacy of Michael Sattler (Scottdale, Pa: Herald Press, 1973), p. 83n.15. 
labelled 'radicals' and why their opposition to the Evangelical reformers and Catholic counter-reformers might in essence be understood as prophetic.

The first year of Anabaptist missionary endeavour is also almost indistinguishable from the movement of political reform underway in The Peasants War. ${ }^{72}$ A careful reading of the Peasants' 12 Articles of 1525 which were composed with the assistance of Hubmaier, illustrates the melding of these two complimentary 'revolutionary' movements:

Since the right tithe is established in the Old Testament and fulfilled in the New, we are ready and willing to pay the fair tithe of grain. [...] We will in the future collect the tithe through our church elders, appointed by the congregation and distribute from it, to the sufficient livelihood of the minister and his family elected by the entire congregation [...] The remainder shall be given to the poor of the place. ${ }^{73}$

This, the peasants' second Article, employs a Christocentric interpretation of Scripture which was being popularized by Luther and Karlstadt. ${ }^{74}$ The wording possibly also reflects Hubmaier responding to Zwingli's backpedalling on adult baptism and related material church reforms in Zurich. The Article radically challenged the economic status quo of the Holy Roman Empire because Anabaptists dared to imagine a new church polity - a way of doing church that would transform decision-making, the appointment of leaders and the use of tithes for the common good an ecclesiology of the baptized, standing in faithful solidarity with the poor. In this way German peasants' grievances echoed the voice of Czech Brethren peasants a half century before, and sounded like an embryonic liberation theology. ${ }^{75}$ It is easy to see why the Peasants' subscription to an

72 An introduction to the historiography is James Stayer's The German Peasants' War and Anabaptist Community of Goods (Montreal and Kingston: McGill-Queens University Press, 1991). For a discussion of sources about Grebel, Mantz and Blaurock's close ties to the Peasant revolts in Grüningen see Snyder, 'The Birth and Evolution of Swiss Anabaptism', pp. 576-578.

73 The Second Article on tithing, quoted in Driver, Radical Faith, p. 172.

74 So, Snyder, Anabaptist History and Theology, pp. 29-30.

75 For primary sources about Peter Chelcicky's clear opposition the medieval hierarchical class system, and his vocal opposition to the Taborite clergy's complicity in this oppression, see Driver, Radical Faith, pp. 135-136. 
Anabaptist ecclesiology, which devolved to the local congregation soleauthority in the stewardship of tithes, along with the later Anabaptist practise of community of goods, became a direct threat to the extractive economy of the Holy Roman Empire.

The reliance of the peasants, in word if not always in spirit, on the newly articulated Anabaptist ecclesiology, is part of the initial evidence this paper wishes to present of the Radical Reformers' prophetic engagement in society. Contrary to the stereotype that may have been encouraged by historians like Harold Bender, of Anabaptists as ubiquitously pacifist, spiritualist and separatist, revisionist approaches to the sources, such as my cursory analysis above, show that the first Radical Reformers pioneered congregational reform among rural peasants while enmeshed in the late medieval struggle for a more just society. ${ }^{76}$ The Swiss Brethren, far from being pietistic separatists, were 'a grassroots, alternative movement of popular reform. ${ }^{177}$ They imagined and realized local congregations free of the age-old concordat with corrupt state powers, and embodied the New Testament grammar of God's Kingdom, animating the Gospel among the poor.

\section{Radical wagers of peace}

A crucial development for this study concerns the commitment to nonviolence which was by no means ubiquitous among South German Anabaptists during the first two years of Radical Reform since Grebel's subscription to a 'defenceless' Christianity in his letter of 1524 to Müntzer. Hubmaier, Brőtli, Reublin and others differed with Mantz and Grebel on the matter of 'the sword' and gave support to the Swabian peasant uprising at Waldshut in battles against troops of the Swabian League in the Hallau and Schaffhausen districts - in what they understood to be a just war. ${ }^{78}$ From January 1525 to December 1526 there was also no uniform linkage of the

76 Further evidence of Sattler's non-violent identification with the Peasants, from Snyder's analysis of the sources, will be presented below.

77 Snyder, Anabaptist History and Theology, p. 51. Snyder's summation of recent debate about separatism versus congregational engagement in society is presented in 'The Birth and Evolution of Swiss Anabaptism', pp. 578-579.

78 Revisions of Bender's 'Anabaptist Vision' by Stayer et al focus on the antithetical approaches to 'the sword' in the Radical Reformation. See Snyder, Anabaptist History and Theology, pp. 51-52. 
ban of Matthew 18 to the Lord's Supper, or uniform teaching that baptism required of Anabaptist churches to reject participation in governments or in armed resistance. ${ }^{79}$ This evidence of diverse theological commitments among leaders from the very beginning of the Radical Reformation, and lively debates about 'the sword' in both theological senses - violence per se, or the sword as Government - underscores how difficult it was for the Evangelical governors of Zurich or Austrian imperial armies to distinguish Anabaptists from peasant revolutionaries.

Despite divergences of opinion about 'the sword,' evidence suggests that commitment to a defenceless Christianity strengthened among a key grouping of Anabaptists in the face of intensifying persecution. By the time of Felix Mantz's farewell letter in early 1527 a Christocentric theology of pacifism and active peace-making was clearly established:

[...] those who wield the sword do not show the love or mercy of Christ, nor follow his example, although they wish to be called shepherds and teachers [...] The true love of Christ shall not destroy the enemy; as the Father in heaven is merciful [...] Christ also never hated anyone; neither did his true servants, but they continued to follow Christ in the true way, as He went before them. ${ }^{80}$

A first defining moment of consensus in the re-baptizers' rejection of the sword was the 'Brotherly Union' or meeting, at the Swiss-German border village of Schleitheim on 24 February 1527. Here, the tradition around the sources suggests Michael Sattler played a significant role in the formulation of seven Schleitheim Articles, and in securing agreement to them by a cross-section of the baptizing pastors. ${ }^{81}$

The agreement of the Brotherly Union to Article IV on separation from 'the world and those who come from the world' included a consequent

79 For example at Zollikon, the earliest Anabaptist group to coalesce into a community, Reublin, Brőtli and others sympathetic to the Peasants War baptized and participated in the Lord's Supper. See Snyder's more detailed discussion in 'The Birth and Evolution of Swiss Anabaptism', pp. 546-548.

80 Thielman van Braght, The Martyr's Mirror, p. 415.

81 Research on Schleitheim is copious. An introduction to the literature is James Stayer's chapter 'Separatist Non-resistance: The Schleitheim Confession and the Swiss Disputations,' in Anabaptists and the Sword, 2nd Edition (Eugene, Oregon: Wipf \& Stock, 2002), 117-132. 
commitment to reject 'all weapons of violence [...] and all of their use to protect friends or against enemies - by virtue of the word of Christ: "You shall not resist evil".' ${ }^{\prime 2}$ Articles VI and VII committed all in agreement at Schleitheim to adopt the non-violent, active posture of peace-making embodied by Christ, by rejecting any coercive role in the State such as that of soldier or magistrate, or taking any oaths of allegiance to the State. ${ }^{83}$

It is not hard to see why the Brotherly Union of 24 February 1524 and the Schleitheim Articles that circulated widely afterward evoked such a swift refutation from Zwingli and equally swift conciliar action to incarcerate and eliminate its authors. ${ }^{84}$ The Schleitheim agreement of the Swiss Brethren effectively laid out the ethics of an alternative politics - a way of doing Church that would break the fourteen-hundred year Constantinian concordat between Church and State and weave the semantics and ethics of Christ's Beatitudes into discipleship - Beatitudinal grammar as normative rather than as a mere aspirational ideal - thereby making any form of coercion antithetical to doing Church.

Arnold Snyder's interpretation of the limited sources extant about Michael Sattler's presence and role at Schleitheim lead to a significant conclusion for the present discussion. Snyder shows that Michael Sattler, the monk of St Peter's of the Black Forest, almost certainly witnessed first-hand the violence of the 1522 Peasant uprising against tithes and the peasants' plunder of monasteries in the Bresgau in early $1525 .{ }^{85}$ Sattler most likely left monastic life when the Peasants Christian Union peacefully took over St Peter's, on 12 May 1525. Snyder demonstrates that Sattler might just as easily have converted to the urbane Lutheranism of Freiberg in Southern Germany as to the Anabaptism of the Forest Peasants. ${ }^{86}$ However, Sattler's ethical

82 Yoder's translation in his The Legacy of Michael Sattler, p. 38.

83 See Yoder, The Legacy of Michael Sattler, pp. 39-40.

84 Zwingli had translated portions of the Schleitheim Seven Articles from four copies in his own possession as part of his written refutation of the Radical Reformers - Contra Catabaptistarum Strophas Elenchus - within 6 months of the Schleitheim meeting, by August 1527. So, Yoder, The Legacy of Michael Sattler, 13. For more on Zwingli's refutation and Michael Sattler's capture, trial and martyrdom, see Arnold C. Snyder, 'Rottenburg Revisited: New Evidence Concerning the Trial of Michael Sattler,' Mennonite Quarterly Review, vol. 54, no. 3 (1980): 208-228.

85 So, Snyder, 'Revolution and the Swiss Brethren', pp. 281-283.

86 'Revolution and the Swiss Brethren', pp. 283-287. 
and theological transformation from being a highly educated member of the Benedictine monastic elite which had buttressed the wealthy Austrian establishment, to a wandering Anabaptist weaver, is best explained as the result of Sattler's evidently sustained and meaningful contact with influential Anabaptists among the revolutionary Peasant brotherhood.

Snyder's revisionist lenses lead to the conclusion that the Schleitheim Articles' agreement for non-violence and separation from the State were not just knee-jerk apolitical and pietistic separatism. On the contrary, the Brotherly Union - if Michael Sattler was indeed its key facilitator as the limited sources suggest - gave to Anabaptism a foundational commitment to the defenceless discipleship of the Sermon on the Mount because Sattler and the other Radical Reformers identified with and supported impoverished peasants in the struggle against coercive taxation by a church in league with Austria's absolute monarch. Schleitheim laid out the alternative and subversive politics of peace-making. Anabaptist non-violence in the mould of the Schleitheim Articles is radical because it sides non-violently with the oppressed, against all powers of coercion, whether in the State or the Church. In this way, Anabaptist ecclesiology may be understood, along with the earlier medieval reform movements, to embrace the Apostolic and prophetic tradition of ante-Nicaean congregations.

\section{Decolonizing the Constantinian imagination in the South African Church}

This study has suggested that the early Anabaptists practised an alternative politics grounded in the peace-making of Jesus' Sermon on the Mount as norms for discipleship in the life and growth of congregations. This commemoration of events during the first years of Anabaptism has reread some early sources at face value, concluding that sixteenth century re-baptizers may be viewed as prophetic and apostolic, not only because they were martyred as defenceless Christians, but equally, because they worked in solidarity with peasants, artisans and exiles - those at the bottom of late-medieval society - to build up the common good in the face of increasingly militant coercion by Church and State. In what remains of this commemoration four key themes from early Anabaptism will be brought into conversation with South African local congregations and presented as lenses through which South African churches might identify 
an invitation to prophetic discipleship, in this five hundredth anniversary year of the Reformation.

A history of the Constantinian marriage between congregations and hegemonic power in South Africa, where Christians tacitly or actively bolstered British Imperialism and Afrikaner Nationalism alike, is well documented elsewhere. ${ }^{87}$ Much work continues on the changing role of the Church and theology in post-Apartheid South Africa, especially in the wake of Archbishop Desmond Tutu's pivotal role in the Truth and Reconciliation Commission of $1999-2000 .{ }^{88}$ There are also fresh perspectives in South African theology searching out new appropriations of an Apostolic, prophetic discipleship that Jesus' Sermon on the Mount invites local congregations to practise, in the current milieu. ${ }^{89}$

Making a leap of resonance from the early Anabaptist story to the complexity of church embroilment in neo-liberalism in South Africa in 2017 risks the danger of generalization, misrepresentation and moralism, and readers of theology in my experience are the most critical listeners to sermons! For this reason the four thematic lenses I introduce, are offered as part of my ongoing challenge as a White South African to recall and appropriate more of the Anabaptist story. My hope is that these four lenses will refract the historiography I have presented into heuristically dialogical, conversational outlines, to encourage local congregations and church leaders of all traditions in South Africa, who are ready to imagine

87 A good overview is the anthology of essays by Richard Elphick and Rodney Davenport, eds., Christianity in South Africa: A Political, Social \& Cultural History (Cape Town: David Phillip, 1997). For the Apartheid period in particular, good introductions are Charles Villa-Vicencio and John de Gruchy, eds., Apartheid is a Heresy (Cape Town: David Philip, 1983) and James Cochrane, Servants of Power: The Role of the Englishspeaking Churches 1903 - 1930 (Johannesburg: Ravan, 1987).

88 So for example, John de Gruchy, Reconciliation: Restoring Justice (Minneapolis, MIN: Fortress Press, 2003); Etienne de Villiers, 'Public Theology in the South African Context,' International Journal of Public Theology, 5 (2011): 5-22 and Victor Masilo Molobi, 'The Past and Future of Black Theology in South Africa: In Discussion with Maimela,' Studia Historiae Ecclesiasticae, vol. 36 (July 2010): 35-48.

89 So, Anthony Balcomb, 'Still Crying the Beloved Country: The Crisis of Morality in South Africa and the (Improbable) Possibility of an Anabaptist Ethic,' Conference paper presented at the ANiSA Conference: Anabaptist Theologies in South Africa, Volmoed, Hermanus, Western Cape, October 2013; and Andrew J. Suderman, 'Who'll be a Witness for my Lord? Witnessing as an Ecclesiological and Missiological Paradigm,' Missionalia, vol. 44, no. 1(2016): 68-84. 
and practise peace-making with inspiration from the Anabaptist tradition, to reanimate the life of the church as politics.

The first thematic lens concerns violence and peace-making, which are of deepening concern to Christians worldwide. ${ }^{90}$ The almost ubiquitous commitment to pacifism among the Swiss Brethren has an obvious resonance for the South African church, particularly in view of South Africa's colonial legacy of slavery and war. How, for example, might an imaginary conversation proceed between Felix Mantz and Michael Sattler and White South African Christians in local churches today? How might White South African Christians respond to the Anabaptist invitation to non-violence in this conversation, in view of the White colonial churches' coercive history. ${ }^{91}$ The relevance of White and Black South African Christians engaging in conversation with Anabaptism for the purpose of jointly remembering a violent history, with the goal of renewed prophetic transformation in the South African local congregations, relates directly to matters of restitution, reconciliation and ultimately, to the resilience and future of Christian witness in this part of the world. How for example, might White Christians respond with integrity in local congregations to the fact the Truth and Reconciliation Commission never required any symbolic or material demonstration of restitution by Whites, towards Black South Africans, for the gross material injustices of Apartheid? ${ }^{92}$ Further reflection about and implementation of prophetic restitution by White South African Christians needs to be undertaken with urgency if South African local

90 A recent study is Stanley Hauerwas and Jean Vanier, Living Gently in a Violent World: The Prophetic Witness of Weakness (Downers Grove, IL: IVP Books, 2008).

91 Besides being the first in South Africa to segregate public gatherings along racial lines, White Christians in the colonial period also participated in genocidal expeditions against the Khoi and San, the sub-continent's First Nations; they accommodated the enslavement of Black and Asian people; went to war to achieve the destruction of African kingdoms; and readily took up arms to fight against other Christians in local, regional and international wars, not least against black Christians in the Apartheid civil war.

92 A good introduction to this topic is James Cochrane, John de Gruchy and Stephen Martin, eds., Facing the Truth: South African Faith Communities and the Truth \& Reconciliation Commission (Cape Town: David Philip Publishers, 1999). For more on the questionable legacy of the TRC for restorative justice and forgiveness between South African communities, see Christian B. N. Gade, 'Restorative Justice and the South African Truth and Reconciliation Process,' South African Journal of Philosophy, vol. 31:1 (2013): 10-35. 
congregations, like Bonhoeffer's prophetic community, might forsake all Constantinian illusions of becoming a 'leading force' in South Africa and simply survive as congregations faithful to Jesus' embodied grammar of God's Kingdom, in an increasingly unjust and violent context. ${ }^{93}$

A second lens relates to the Radical Reformers' intentional relinquishment of all forms of secular, conciliar power, citizenship and domicile, all of which Mantz, Grebel, Sattler, Hubmaier and the other Swiss Anabaptists surrendered when they were defrocked from their church offices and exiled from their homes under pain of imprisonment or death. Anabaptists' defenceless co-abandonment to God's will - their gelassenheit - was the antithesis of the age-old Constantinian will to power. ${ }^{94}$ How might South African congregations transform if Christian leaders began to do church as politics - the politics of the Sermon on the Mount - and surrendered a dualistic worldview that suggests 'Christian hands' should take hold of levers of civic or indeed State power in a quest to 'exert 'political' influence' by conciliar agency? ${ }^{95} \mathrm{~A}$ truly prophetic witness that is continuous with biblical and Apostolic precedents, this commemorative remembering of the Schleitheim Articles wants to suggest, may only be achieved corporately by local congregations whose leaders who have relinquished any ambition of directing the course of history. ${ }^{96}$

93 Stanley Hauerwas aptly summarizes this posture of radical self-abandonment to the purposes of God through the common life of the local congregation, when he says, 'the first task of the church is not to make the world just, but to make the world the world.' Stanley Hauerwas, 'What could it mean ...?' (1997), p. 21.

94 Anabaptist gelassenheit embodied among Christian leaders in South Africa would run counter to the strong ebullient mind-set described in the introduction to this study. See Stanley Hauerwas' fuller exposition of the Constantinian wilfulness of Christendom in After Christendom: How the Church Is to Behave If Freedom, Justice and a Christian Nation Are Bad Ideas (Nashville, Ten: Abingdon Press, 1991).

95 I am indebted to Dan Nyswander for humorously exemplifying an Anabaptist tradition of respectful theological distrust in democracy and governments in general - which I have subsequently explored by reading more widely in the Anabaptist theological heritage. See for example, John Howard Yoder, The Politics of Jesus: Vicit Agnus Noster (Grand Rapids, MI: Eerdmans, 1972) and almost any monograph in Hauerwas' corpus.

96 A thought-provoking survey of the theology and implications of Anabaptist gelassenheit in the context of contemporary South African Christianity, is Andrew Suderman, 'In Search of Prophetic Theology: South African Political Theology in Dialogue with Anabaptism,' PHD Thesis (Pietermaritzburg: University of KwaZulu-Natal, currently under examination). 
The third theme relates directly to the two lenses introduced above, and concerns the Radical Reformers' close identification with the oppressed. Hubmaier's risk in offering sanctuary to peasant emigres and his solidarity with their cause in sacrificially availing his time and expertise; Sattler's disappearance from the offices of one of the elite monasteries of the realm, to learn weaving among peasants in the Black Forest; and Mantz, Grebel, Blaurock and Hottinger's itinerant life on the run, among rural peasants in the Zurich hinterland, it has been suggested, were prophetic and Apostolic. The Swiss Brethren, like John the Baptist, had a most subversive effect on the ruling authorities because of their solidarity with the oppressed, with identical consequences.

To what extent, it might then be asked, are local congregations and Church leaders in South Africa offering sanctuary, resources and expertise in the struggle for justice to all who are marginalized by the capitalist hegemony of neo-liberalism. Do the homeless, the landless, the foreign nationals who are refugees, orphans or the aged, or those stigmatized on account of gender, sexual orientation or disability find welcome in local South African churches? Are South African congregations taking the opportunity to deconstruct the institutionalized, homogenously Black or White churches of one economic class, which predominated in the days of Apartheid, to animate a prophetic life together? Such a prophetic congregational life David Bosch might have described as the experimental garden of God's Kingdom, little outposts of the new creation, bringing God's in-breaking freedom and joy to the poor and downtrodden.

A final thematic lens in the Anabaptist historical sources I have freshly unearthed is really a fourth facet in a kind of multi-focal lens along with the three described above - that of the Swiss Brethren's common life - their corporate understanding of salvation as immersion of individual faith in Christ into the common life of the worshipping community. Anabaptist fellowship was expressed as meaningfully at the Lord's Supper as in their congregational economics of wellbeing - always in practical sympathy with the wider good. As we have seen, the commitment of most Anabaptists to congregational decision-making about tithes and some Anabaptist groupings' sharing of a common purse, effectively subverted the culture of financial corruption, extortion and aggrandisement in late medieval churches and became a direct threat to the extractive economy of the Holy 
Roman Empire. Embodying this sixteenth century European example of ubuntu is possible in local congregations in South Africa, which too often are a mirror image of one of the world's most unequal societies. What prophetic witness to the Gospel of reconciliation and peace could arise in every village, town, suburb or inner city district of South Africa, if local congregations were communities of restitution practising an alternative economics based on the Beatitudes, boldly flying in the face of extortive capitalism?

\section{Conclusion}

This discussion has reconstructed a narrative of the Anabaptist Radical Reformers' ways of doing church, which for the most part embodied and exemplified what might be seen as a prophetic Christian witness and presence in the tradition of the apostolic church of the first century. Returning to these memories of Anabaptists' first years of evangelism and congregational life, with a second naiveté, has apprehended the exigencies of the re-baptizers' marginal existence in the face of Empire. Reading again at face value, from their letters, catechisms and Articles, has commemorated their robust faith and courageous stand alongside the weak in the face of transgressive, a hegemonic Christendom. With just a few allusions to the accounts, we have been reminded of that woeful litany of ills that has come of the Christian church's love affair with power in its totalizing magisterial, national or local forms.

The theological genealogy of the local church sketched in this research has been related to the wisdom of Achille Mbembe's philosophical genealogy of capitalism. Mbembe's words about the default posture of extractive capitalism may have been used as aptly to describe the period of the Reformation commemorated in this study, a posture of:

habituating oneself to the deaths of others - slow death, death by asphyxiation, sudden death, delegated death [...] accommodations with the deaths of others, of those with whom we imagine to have shared nothing ... ${ }^{\prime 97}$

97 Achille Mbembe, Critique of Black Reason, trans. Laurent Dubois (Johannesburg: Wits University Press, 2017), 183. 
While this research has intentionally focused on North American and South African Christianity, these can be understood equally as embodiments of Mbembe's broader organizing metaphor. Christianity in South Africa and North America has too often been indistinguishable from capitalism or liberalism, so that

'these many ways in which the springs of life are dried up in the name of race and difference, have all left deep traces in both imagination and culture and within social and economic relations.' ${ }^{98}$

The endeavours of this study are futile unless they lead to a radical reimagining and re-animation of local churches in South Africa. As did prophets of every earlier age, the mission and witness of the Radical Reformers invites us to return to the local church's truest charter - the New Testament grammar of God's Kingdom - in radical surrender to practise the ethics of Jesus' Sermon on the Mount. The Christian prophetic tradition enjoins us not to leave politics to those who govern, but to embody the politics of the Triune God whose love is cruciform. This challenge is to practise the politics of Jesus' peaceable Kingdom, in discipleship that eschews coercion and champions the common good. Commemorating the early Anabaptist martyrs invites us not only to read the Beatitudes as ideals but to live them as ethics. We are invited to do church with love that will reverse and heal the painful legacies of hegemonic Christendom, knowing that such sacrificial love is the germinal of God's new creation.

\section{References}

Balcomb, Anthony. 'Still Crying the Beloved Country: The Crisis of Morality in South Africa and the (Improbable) Possibility of an Anabaptist Ethic.' In ANiSA Conferece: Anabaptist Theologies in South Africa. Volmoed, Hermanus, Western Cape, 2013.

Bassett, Caroline. 'Neoliberal South Africa after Apartheid: A Better Life

Betrayed.' Canadian Dimension 48, no. 2 (March/April 2014).

Bender, Harold S. 'The Anabaptist Vision.' The Mennonite Quarterly

Review 18 (April 1944): 67-88.

98 Ibid., 183. 
- 'The Anabaptist Vision.' Church History 3 (March 1933): 3-24.

Bergen, Jeremy M. 'Lutheran Repentance at Stuttgart and Mennonite

Ecclesial Identity.' Mennonite Quarterly Review 86, no. 3 (July 2012).

Berry, Wendell. Sex, Economy, Freedom and Community: Eight Essays.

New York: Pantheon Books, 1992.

Biesecker-Mast, Gerald 'Anabaptist Separation and Arguments against the Sword in the Schleitheim Brotherly Union.' Mennonite Quarterly Review 74, no. 2 (2000).

Bonhoeffer, Dietrich. Life Together. London: SCM, 1954.

Brock, Peter. The Political and Social Doctrines of the Unity of the Czech Brethren. The Hague: Mouton and Co., 1957.

'Church in Action: National Church Leaders Forum Makes Strong Call on Anc to Act.' [Online] Available: http://ngkok.co.za/ kennisg/201715/2017-04-20\%20SACC-Statement-on-State-of-South-Africa.pdf [Accessed: 15 June 2017].

'The Citizen: Don't Make an Enemy of the Church, Pityana Warns Zuma.' [Online] Available: http://citizen.co.za/news/news-national/1365271/dont-makemore-enemies-pityana-warns-zuma/ [Accessed: 15 June 2017].

Cochrane, James. Servants of Power: The Role of the English-Speaking Churches 1903-1930 Johannesburg: Ravan, 1987.

Cochrane, James, John de Gruchy and Stephen Martin, ed. Facing the Truth: South African Faith Communities and the Truth \& Reconciliation Commission. Cape Town: David Philip, 1999.

The Con Magazine: There Is Only One World: Epilogue of Achille Mbembe's. Critique of Black Reason, http://www.theconmag.c0.za/2017/07/19/ There-Is-Only-One-World/ [Accessed 16 August 2017].

'The Conversation, the Political Theology of Jacob Zuma, by Roger Southall.' [Online] Available: http://theconversation.com/the-political-theologyof-jacob-zuma-71176 [Accessed: 17 May 2017].

Davenport, Richard Elphick and Rodney, ed. Christianity in South Africa: A Political, Social \& Cultural History. Cape Town: David Phillip, 1997. 
de Gruchy, John, Charles Villa-Vicencio eds. Apartheid Is a Heresy. Cape Town: David Phillip, 1983.

de Gruchy, John and Steve de Gruchy. The Church Struggle in South Africa, Twenty-Fifth Anniversary Edition. Mineapolis, MIN: Fortress Press, 2005.

de Gruchy, John. Reconciliation: Restoring Justice. Minneapolis, MIN: Fortress Press, 2003.

de Nieto, José. Juan De Valdés and the Origins of the Spanish and Italian Reformation. Geneva: Libraire Doz, 1970.

de Villiers, Etienne. 'Public Theology in the South African Context.' International Journal of Public Theology 5 (2011): 5-22.

Driver, John. Radical Faith: An Alternative History of the Christian Church. Kitchener, Ontario: Pandora, 1999.

Durnbaugh, Donald F. The Believers' Church: The History and Character of Radical Protestantism. New York: The MacMillan Company, 1968.

Dyk, Cornelius J. Introduction to Mennonite History: A Popular History of the Anabaptists and the Mennonites. Scottdale, PEN: Herald Press, 1993.

Elphick, Richard and Rodney Davenport, ed. Christianity in South Africa: A Political, Social \& Cultural History. Cape Town: David Philip, 1997.

'Eyewitness News: Zuma Skips Poliltics, Asks for Congregants to Pray for South Africa.' [Online] Available: http://ewn.co.za/2017/04/14/zuma-skipspolitics-asks-congregants-to-pray-for-sa [Accessed: 15 June 2016].

Finger, Thomas N. '[Responses to Snyder].' Mennonite Quarterly Review 80, no. 4 (2006): 660-66.

Friedrich, Gerhard Kittel and Gerhard, ed. Theological Dictionary of the New Testament. Grand Rapids, MI: Eerdmans, 1985.

Gade, Christian B. N. 'Restorative Justice and the South African Truth and Reconciliation Process.' South African Journal of Philosophy 32, no. 1 (2013/03/01 2013): 10-35. 
Goddard, Allen J. 'Beginnings, the Ending and Africa's Century of Anabaptist Witness, in Between.' In Anthology of African Christianity, edited by Isobel and Dietrich Werner Phiri. Pietermaritzburg: Cluster Publications, 2016.

Gordon, Sarah Frances, Anthony Collins. 'We Face Rape. We Face All Things: Understandings of Gender-Based Violence Amongst Female Students at a South African University '. African Safety Promotion: A Journal of Injury and Violence Prevention 11, no. 2 (2013): 93-106.

Gregory, Brad. Salvation at Stake: Christian Martyrdom in Early Modern Europe. Harvard: Harvard University Press, 1999.

Hauerwas, Stanley and Jean Vanier. Living Gently in a Violent World: The Prophetic Witness of Weakness. Downers Grove, IL: IVP Books, 2008.

Hauerwas, Stanley. After Christendom: How the Church Is to Behave If Freedom, Justice and a Christian Nation Are Bad Ideas. Nashville, TEN: Abingdon Press, 1991.

- In Good Company: The Church as Polis. Notre Dame: IND: University of Notre Dame Press, 1995.

- 'What Could It Mean for the Church to Be Christ's Body: A Question without a Clear Answer.' In In Good Company: The Church as Polis. Notre Dame, IN: University of Notre Dame Press, 1997.

Hornus, Jean-Michel. It Is Not Lawful for Me to Fight: Early Christian Attitudes Towards War, Violence \& the State. Translated by Oliver Coburn Alan Kreder. Eugene, Oregon: Wipf \& Stock.

Kinghorn, Johan. 'The Theology of Separate Equality.' In Christianity in South Africa, edited by Martin Prozesky. Bergvlei, South Africa: Southern Book Publishers, 1990.

Kreider, Alan. The Change in Conversion and the Origin of Christendom. Eugene Oregon: Wipf \& Stock, 2007, First published by Trinity Press International in 1999.

- 'Christianity Today: God's Left Wing: The Radical Reformers, [Online] Available: http://www.christianitytoday.com/history/issues/issue-9/GodsLeft-Wing-Radical-Reformers.html [Accessed: 13 June 2017]. 
- The Patient Ferment of the Early Church: The Improbably Rise of Christianity in the Early Church. Grand Rapids, MI: Baker Academic, 2016.

La Mothe, Ryan. 'neoliberal Capitalism and the Corruption of Society: A Pastoral Political Analysis.' Pastoral Psychology 65 (2016): 5-21.

Madonsela, Thuli. 'State of Capture.' Cape Town: Office of the Public Protector, Report no. 6 2016/2017.

Mail\&Guardian, 6 January 2017, 'Zuma Takes Soweto to Church as He Compares the Anc to Jesus Christ,' [Online]. Available: https://mg.co.za/ Article/2017-01-06-Zuma-Takes-Soweto-to-Church-as-He-Compares-the-Anc-to-JesusChrist [Accessed: 15 June 2017].

Mbembe, Achille. Critique of Black Reason. Johannesburg: Wits University Press, 2017.

Molobi, Victor M. 'The Past and the Future of Black Theology in South Africa: In Discussion with Maimeal.' Studia Historiae Ecclesiasticae 36 (July 2010).

Munusamy, Rajeni. 'Betrayal of the Promise: The Anatomy of State Capture.’ Daily Maverick, 26 May 2017.

Osborne, Troy. 'Arnold Snyder's "In Search of the Swiss Brethren": A Response.' [In Eng]. Mennonite Quarterly Review 90, no. 4 (2016): 517-32.

Ricoeur, Paul. Essays on Biblical Interpretation, Ed. Lewis S. Mudge. Philadelphia: Fortress Press, 1980.

Roth, John D. 'Recent Currents in the Historiography of the Radical Reformation.' Church History 71, no. 3 (2002): 523-35.

Schultz, Robert C., ed. The Christian in Society. Edited by helmut T. Lehmann Vol. 46, Luther's Work,. Philadelphia: Fortress Press, 1967.

Shellnutt, Kate, Southern Baptists Approve Alternate Resolution Against the Alt-right, Christianity Today, 14 June 2017, [Online] Available: http://www.christianitytoday.com/news/2017/june/southern-baptists-vote-resolutionagainst-alt-right-sbc17.html [Accessed: 15 June 2017]. 
Sider, Ronald. The (Un)Common Good: How the Gospel Brings Hope to a Divided World. Grand Rapids, MI: Brazos Press, 2015.

Snyder, Arnold. Anabaptist History and Theology: Abridged Student Edition. Kitchener, Ontario: Pandora Press, 1995.

- 'Gelassenheit' and Anabaptist Spirituality: Balthasar Hubmaier's Catechism of 1526.' Conrad Grebel Review 9, no. 1 (1991): 1-71.

- 'The Life of Michael Sattler Reconsidered.' Mennonite Quarterly Review 52 (1978): 328-32.

- 'Rottenburg Revisited: New Evidence Concerning the Trial of Michael Sattler.' Mennonite Quarterly Review 54, no. 3 (July 1980): 208-28.

Snyder, C Arnold. 'The Birth and Evolution of Swiss Anabaptism (15201530).' Mennonite Quarterly Review 80 (2006): 501-645.

Snyder, C. Arnold. 'In Search of the Swiss Brethren.' [In eng]. Mennonite Quarterly Review 90, no. 4 (2016): 421-515.

- 'Revolution and the Swiss Brethren: The Case of Michael Sattler.' Church History 50, no. 3 (1980): 276-87.

"Sojourners: History Will Judge Today's Christians According to These 4 Questions, Stephen Matthson, 17 February 2016, [Online] Available: https://Sojo.Net/Articles/4-Moral-Questions-Facing-Modern-Christianity [Accessed: 24 August 2017].

Stanley, Brian. The Gospel and the Flag: Protestant Missionaries \& British Imperialism in the Nineteenth \& Twentieth Centuries Leicester: Apollos, 1990.

Stayer, James. Anabaptists and the Sword. Eugene, Oregon: Wipf \& Stock, 2002.

- The German Peasants' War and Anabaptist Community of Goods. Montreal and Kingston: McGill-Queens' University Press, 1991.

- 'Separatist Nonresistance: The Schleitheim Confession and the Swiss Disputation.' In Anabaptists and the Sword, $2^{\text {nd }}$ Edition edited by James Stayer. Eugene, OR: Wipf \& Stock, 2002.

Stayer, James, Werner O. Packull, and Klaus Depperman. 'From Monogenesis to Polygenesis: The Historical Discussion of Anabaptist Origins.' Mennonite Quarterly Review 49 (1975): 83-92. 
Suderman, Andrew G. 'In Search of Prophetic Theology: South African Political Theology in Dialogue with Anabaptism.' PhD Thesis, University of KwaZulu-Natal, Forthcoming.

- 'The Mennonite Experience in South Africa: An Alternative Imagination.' Mennonite Quarterly Review 89 (2015): 253-74.

- 'Who'll Be a Witness for My Lord? Witnessing as an Ecclesiological and Missiological Paradigm.' Missionalia 44, no. 1 (2016): 68-84.

Swilling, Mark, ed. 'Betrayal of the Promise: How South Africa Is Being Stolen.' In State Capacity Research Project. Stellenbosch: Centre for Complex Systems in Transition, 2017.

Tonder, Helené van. 'Interview with Philippe Denis,' Acta Theologica 35, no. 1 (2015).

Van Braght, Thieleman J. trans. Joseph Sohm. The Bloody Theater or Martyrs Mirror. Scottdale, Pa: Herald Press, 1972.

Van Wyngaard, Cobus. 'The Church as Alternative Community and the Struggle for Liberation in the Work of David Bosch." Dutch Reformed Theological Journal 54, no. 3\&4 (September and December 2013): 1-11.

Villa-Vicencio, Charles. Theology and Violence: The South African Debate. Grand Rapids, MI: Eerdmans, 1988.

Volf, Miroslav. After Our Likeness: The Church as the Image of the Trinity. Grand Rapids, MI: Eerdmans, 1998.

Williams, George H., ed. Spiritual and Anabaptist Writers. Philadelphia: Westminster Press, 1957.

Woods, Chris. Sudden Justice: America's Secret Drone Wars. Oxford: Oxford University Press, 2015.

Wright, Tom. Surprised by Hope. London: SPCK, 2007.

Yoder, John H, ed. The Legacy of Michael Sattler. Scottdale, Pa: Herald Press, 1973.

- The Politics of Jesus: Vicit Agnus Noster. Grand Rapids, MI: Eerdmans, 1972. 
Yoder, Perry. Shalom: The Bible's Word for Salvation, Justice \& Peace. Nappanee, IND1987.

Zizioulas, John. Being as Communion: Studies in Personhood and the Church, Contemporary Greek Theologians Series No. 4. Crestwood, NY: St Vladimir's Press, 1985. 